\title{
Macro and microminerals: are frozen fruits a good source?
}

\author{
PATRICIA D.S. SPADA ${ }^{1}$, GIOVANA V. BORTOLINI ${ }^{1}$, DANIEL PRÁ ${ }^{2}$, CARLA E.I. SANTOS ${ }^{3}$, \\ JOHNNY F. DIAS ${ }^{3}$, JOÃO A.P. HENRIQUES ${ }^{1,4}$ and MIRIAN SALVADOR ${ }^{1}$ \\ ${ }^{1}$ Universidade de Caxias do Sul (UCS), Instituto de Biotecnologia \\ Rua Francisco Getúlio Vargas, 1130, 95070-560 Caxias do Sul, RS, Brasil \\ ${ }^{2}$ Universidade Federal do Rio Grande do Sul (UFRGS), PPG em Genética e Biologia Molecular \\ Av. Bento Gonçalves, 9500, Campus do Vale, 91501-970 Porto Alegre, RS, Brasil \\ ${ }^{3}$ Universidade Federal do Rio Grande do Sul (UFRGS), Laboratório de Implantação Iônica, Instituto de Física \\ Av. Bento Gonçalves, 9500, Campus do Vale, 91501-970 Porto Alegre, RS, Brasil \\ ${ }^{4}$ Universidade Luterana do Brasil (ULBRA), Av. Farroupilha, 8001, Bairro São José, 92425-900 Canoas, RS, Brasil \\ Manuscript received on September 3, 2009; accepted for publication on August 11, 2010
}

\begin{abstract}
Fruits are rich in minerals, which are essential for a wide variety of metabolic and physiologic processes in the human body. The use of frozen fruits has greatly spread in the last years not only in the preparation of juices, but also as raw material for yogurts, candies, cookies, cakes, ice creams, and children's food. However, up to now there is no data about the mineral profile of frozen fruits. This is the first database to quantify the levels of minerals in 23 samples of frozen fruits, including the most used around the world and some native fruits from the Amazon rainforest in Brazil. Considering the Dietary Reference Intakes, $100 \mathrm{~g}$ of frozen fruits can provide 0.2 to $2.8 \%$ of macro and 2.5 to $100 \%$ of microminerals for adults (31-50 years old). Although geographical differences should be considered, these data can help to plan diets and to develop population interventions aiming to prevent chronic diseases.
\end{abstract}

Key words: diet, dietary recommendations, Dietary Reference Intakes, frozen fruits, minerals.

\section{INTRODUCTION}

Many of the current diets are rich in fat, salt, and sugar, and poor in complex carbohydrates, vitamins and minerals, and are responsible for an increase in diet-related diseases such as obesity, diabetes, cardiovascular problems, hypertension, osteoporosis, and cancer. It is believed that the ingestion of fruits and vegetables helps to prevent these diseases. Fruits are important components of diet, responsible not only for adding a variety of color and texture to meals, but also for providing essential nutrients. Fruits are low-fat and low-calorie foods, with relatively small amounts of protein and carbohydrates. However, they are rich in fibers and add a lot of significant micronutrients to the human diet (Zhi et al. 2003).

Correspondence to: Mirian Salvador

E-mail: msalvado@ucs.br
Among the micronutrients found in fruits, minerals represent a class of inorganic substances that is present in all kinds of fruits. The human body needs about twenty different minerals in order to function properly (Williams 2006). These elements can be classified into macro and microminerals. Macro minerals are needed in amounts higher than $100 \mathrm{mg} /$ day and include calcium $(\mathrm{Ca})$, phosphorus $(\mathrm{P})$, magnesium $(\mathrm{Mg})$, sulfur $(\mathrm{S})$, sodium $(\mathrm{Na})$, chloride $(\mathrm{Cl})$ and potassium $(\mathrm{K})$. Microminerals (needed in amounts lower than $100 \mathrm{mg} /$ day) include elements such as iron (Fe), zinc ( $\mathrm{Zn})$, iodine (I), selenium ( $\mathrm{Se}$ ), manganese ( $\mathrm{Mn})$, chromium $(\mathrm{Cr})$, copper $(\mathrm{Cu})$, molybdenum (Mo), fluorine $(\mathrm{F})$, boron $(\mathrm{B})$, cobalt (Co), silicon ( $\mathrm{Si}$ ), aluminum ( $\mathrm{Al}$ ), arsenic (Ar), tin ( $\mathrm{Sn}$ ), lithium (Li) and nickel (Ni) (Mahan and Escott-Stump 2005). Fruits are the most important source of both macro and microminerals (Pellerano et al. 2008), which 
are indispensable for the maintenance of life, growth, and reproduction (Alsafwah et al. 2007).

Nowadays, a diet that is rich in fruits is associated with a reduced risk of many diseases (Genkinger et al. 2004). However, it is difficult to find fruits in natura - which are perishable - during all year round and/or in places far from the harvesting field. The intake of frozen fruits has widely spread in many countries. They are easy to commercialize and are an important source of raw material. They can be used in yogurts, candies, cookies, cakes, ice creams, fresh drinks and children's food (Hassimotto et al. 2005). In a recent work (Spada et al. 2008), it was demonstrated that fruits, even frozen, are rich in carotenoids, ascorbic acid and phenolic compounds and present an important antioxidant activity. However, to our knowledge, there is no data about mineral levels in frozen fruits. Therefore, the aim of this study was to determine the mineral levels in 23 samples of frozen fruit through PIXE (Particle Induced Xray Emission) technique. The results can be important to help the population to achieve the recommended dietary allowance (RDA) threshold for minerals.

\section{MATERIALS AND METHODS}

\section{FROZEN FRUITS}

Frozen pulp of acerola (Malpighia glabra L.), apple (Malus domestica B.), acai (Euterpe oleracea L.), black mulberry (Morus nigra M.), cashew apple (Anacardium occidentale L.), coconut (Cocos nucifera L.), cupuacu (Theobroma grandiflorum W.), kiwi fruit (Actinidia chinensis P.), mango (Mangifera indica L.), melon ( $\mathrm{Cu}$ cumis melo L.), papaya (Carica papaya L.), passion fruit (Passiflora alata C.), peach (Prunus persica L.), pineapple (Ananas sativus L.), raspberry (Rubus idaeus L.), red guava (Psidium guajava L.), soursop (Annona muricata L.), strawberry (Fragaria vesca L.), Surinam cherry (Eugenia uniflora L.), and frozen juice of red grape (Vitis vinifera L.), lemon (Citrus limon B.), orange (Citrus aurantium L.) and tangerine (Citrus reticulata L.) were obtained from the company Mais Fruta (Antonio Prado, RS, Brazil). Pulps and juices were produced with fresh and clean fruits, free of filthy substances, parasites, and plant or animal debris. Only edible portions of the fruits were pressed in order to prepare pulps and juices. With regard to red grape, lemon, orange, and tangerine juices, flesh was separated from the fluid that was obtained from pressing. Pulps and juices were divided into $100 \mathrm{~g}$ aliquots and kept frozen at $-20^{\circ} \mathrm{C}$. No organophosphorus or carbamate pesticides were detected in the samples, through assay described by Bastos et al. (1991) and de Lima et al. (1996).

\section{PARTICLE INDUCED X-RAY EMISSION ANALYSIS}

Quantification of mineral compounds that are present in frozen fruits was carried out using PIXE. This technique has a truly multielemental capability, that is, all elements with atomic number higher than 11 can be simultaneously detected in a single measurement on the same target (Johansson et al. 1995). The sensitivity is very good (of about a few parts per million) and ranges smoothly as a function of atomic number. It is important to note that PIXE sensitivity depends on the sample being analyzed. The analysis is relatively fast and usually takes a few minutes. Since this technique is nondestructive, it preserves the original samples, allowing additional measurements if required. Sample preparation in its solid form (for a variety of samples) does not require any sophisticated handling or chemical treatment, thus drastically reducing any chance of contamination. Nowadays, PIXE is widely used to characterize a variety of materials, including biological, geological and environmental samples (Kern et al. 2005, Franke et al. 2006). For PIXE analysis, fruit samples were dried, crushed and pressed into pellets, as described by (Franke et al. 2006). Measurements were carried out at the Ion Implantation Laboratory of the Physics Institute of the Federal University of Rio Grande do Sul. A 3 MV Tandetron accelerator provided a $2 \mathrm{MeV}$ proton beam with an average current of $2 \mathrm{nA}$ at the targets. The characteristic X-rays induced by the proton beam were detected by a lithium doped silicon detector with an energy resolution of $155 \mathrm{eV}$ at $5.9 \mathrm{keV}$, positioned at an $135^{\circ}$ angle considering the beam direction. The data were analyzed using the GUPIX code (Maxwell et al. 1989, Campbell et al. 2000). The standardization procedure was carried out using an apple leaf standard from NIST (SRM-1515). All assays were performed in triplicate and results were expressed in $\mathrm{mg} \%(\mathrm{w} / \mathrm{w})$. 


\section{StATISTICAL ANALYSIS}

Data were subjected to analysis of variance and means were compared using Tukey's post-hoc test using the SPSS program, version 12.0 (SPSS, Chicago, IL).

\section{RESULTS AND DISCUSSION}

This is the first work to evaluate the mineral content of 23 frozen fruits, including the most used around the world and some native fruits from the Amazon rainforest in Brazil. Frozen fruits are used not only in the preparation of juices, but also as raw material for yogurts, candies, cookies, cakes, ice creams, and children's food (Spada et al. 2008).

The mineral content found in fruits is presented as macro (Table I) and microminerals (Table II). The Dietary Reference Intakes (DRI), defined as the average daily intake level sufficient for meeting the nutrient requirements of nearly all - 97 to $98 \%$ - healthy individuals in a particular life stage and gender group, is also shown. Where there was insufficient scientific evidence to establish a DRI, we used the Dietary Recommendation (DR), which is the recommended average daily nutrient intake level based on observed or experimentally determined estimates nutrient intake by a group, or groups, of apparently healthy people assumed to be in an adequate nutritional state (IOM 2004). All fruits here studied had $\mathrm{Mg}, \mathrm{Cl}, \mathrm{P}, \mathrm{K}$ and $\mathrm{Ca}$. Sulfur was found in all fruits, except in cupuacu and passion fruit, native Brazilian fruits. Only coconut, lemon and papaya presented $\mathrm{Na}$.

The micro mineral $\mathrm{Fe}$ was found in all fruits, Mn in $65.2 \%$ of them, and $\mathrm{Cu}$ and $\mathrm{Zn}$ in $30.4 \%$ of the analyzed fruits. A low level of $\mathrm{Cr}$ was found in melon, orange and papaya. The microminerals $\mathrm{Si}$ and $\mathrm{Al}$ were found in $91.30 \%$ and $39.13 \%$ of fruits, respectively.

Macro minerals are essential for a wide variety of metabolic and physiologic processes in the human body. $\mathrm{Ca}, \mathrm{Mg}, \mathrm{K}, \mathrm{Na}$ and $\mathrm{Cl}$, for example, are important for many enzymatic activities, for the composition of the skeletal system, and for ATP formation (Williams 2006).

It was observed that frozen fruits $(100 \mathrm{~g})$ are able to provide around $2.1 \%$ (men) and $2.8 \%$ (women) of the DRI for $\mathrm{Mg}$, which acts as a cofactor for over 300 proteins. It also influences bone quality, decreasing hydroxyapatite crystal size, and thereby, preventing the larger crystals that could lead to brittle bone (Bonjour et al. 2009).

Around $0.5 \%$ (both sexes) of the DRI for $\mathrm{Ca}$ and $\mathrm{P}$ can be supplied by $100 \mathrm{~g}$ of frozen fruits. Calcium provides strength and hardness to bones and teeth, and mediates vascular constriction and vasodilation, muscle contraction, transmission of nerve impulses and blood clotting (Krall 2000). Phosphorus is also a constituent of bones (Bonjour et al. 2009), but when in high levels, it could lead to $\mathrm{Ca}$ metabolism disorders because of a drop in the plasma concentration of ionized $\mathrm{Ca}$, and secondary hyperparathyroidism (Bonjour et al. 2009).

Chloride, potassium and sodium were found in small amounts, reaching only about $0.2 \%$ of the DR. These minerals present important roles in the control of cardiac output and peripheral vascular resistance, which are the main determinants of the blood pressure level (Karppanen et al. 2005). $\mathrm{Cl}$ and $\mathrm{Na}$ were believed to be readily equilibrated and achieving iso-osmolality with blood (Titze and Ritz 2009). In excess, these elements can produce hyperchloraemic acidosis, renal vasoconstriction and reduced glomerular filtration rate (Lobo 2004).

Frozen fruits $(100 \mathrm{~g})$ can provide about $3.5 \%$ (men) and $1.5 \%$ (women) of the DRI for Fe. Acai, apple and tangerine are rich in Fe, and $100 \mathrm{~g}$ of these frozen fruits can contribute to approximately $7 \%$ of the DRI for men. Red grape and coconut (100 g) can reach $22.2 \%$ of the Mn DRI. All fruits can provide more than $100 \%$ of the $\mathrm{Cu}$ DRI for men and women. Levels of $\mathrm{Zn}$ found in frozen pulps are able to supply about $2 \%$ of DRI for men and 3\% for women. Microminerals such as Fe, $\mathrm{Mn}, \mathrm{Cu}$ and $\mathrm{Zn}$ are cofactors of many enzymes and part of the active site of some oxidases and oxygenases (Halliwell and Gutteridge 2007). Iron is a component of hemoglobin, myoglobin, cytochromes, and a lot of enzymes in the muscle cells (Donabedian 2006). Manganese is a micro mineral that is found in all tissues and is required for normal amino acid, lipid, protein, and carbohydrate metabolism (Aschner and Aschner 2005). It is also a microcomponent of metalloenzymes such as arginase, glutamine synthetase, phosphoenolpyruvate decarboxylase, and Mn superoxide dismutase (Aschner and Aschner 2005). Mn is involved in immune func- 
TABLE I

Level of macrominerals $(\mathrm{mg} \%)$ in frozen fruits.

\begin{tabular}{|c|c|c|c|c|c|c|c|}
\hline Samples & $\mathrm{Mg}$ & $\mathrm{Cl}$ & $\mathrm{P}$ & $\mathrm{Ca}$ & $\mathrm{K}$ & $\mathrm{S}$ & $\mathrm{Na}$ \\
\hline Acai & $8.47 \pm 0.17^{\mathrm{a}}$ & $1.96 \pm 0.12^{\mathrm{a}}$ & $3.05 \pm 0.07^{\mathrm{a}}$ & $3.50 \pm 0.13^{\mathrm{a}}$ & $1.03 \pm 0.40^{\mathrm{a} *}$ & $1.91 \pm 0.01^{\mathrm{a}}$ & nd \\
\hline Acerola & $8.64 \pm 0.22^{\mathrm{a}}$ & $2.38 \pm 0.19^{\mathrm{a}}$ & $3.25 \pm 0.16^{\mathrm{a}}$ & $5.82 \pm 0.05^{\mathrm{b}}$ & $1.22 \pm 0.50^{\mathrm{b}}$ & $2.17 \pm 0.09^{\mathrm{ab}}$ & nd \\
\hline Apple & $7.74 \pm 0.24^{\mathrm{a}}$ & $2.05 \pm 0.02^{\mathrm{a}}$ & $2.61 \pm 0.14^{\mathrm{a}}$ & $3.60 \pm 0.50^{\mathrm{a}}$ & $0.97 \pm 0.10^{\mathrm{a}}$ & $1.73 \pm 0.03^{\mathrm{a}}$ & nd \\
\hline Black mulberry & $8.21 \pm 0.05^{\mathrm{a}}$ & $2.26 \pm 0.04^{\mathrm{a}}$ & $3.01 \pm 0.42^{\mathrm{a}}$ & $4.83 \pm 0.02^{\mathrm{c}}$ & $1.35 \pm 0.30^{\mathrm{b}}$ & $1.99 \pm 0.07^{\mathrm{a}}$ & nd \\
\hline Cashew apple & $8.22 \pm 0.01^{\mathrm{a}}$ & $2.99 \pm 0.34^{b}$ & $2.53 \pm 0.47^{\mathrm{c}}$ & $3.49 \pm 0.05^{\mathrm{a}}$ & $1.43 \pm 0.10^{\mathrm{b}}$ & $1.46 \pm 0.55^{\mathrm{a}}$ & nd \\
\hline Coconut & $9.67 \pm 0.24^{\mathrm{a}}$ & $2.60 \pm 0.01^{\mathrm{a}}$ & $4.43 \pm 0.09^{b}$ & $7.60 \pm 0.59^{d}$ & $2.41 \pm 0.16^{\mathrm{b}}$ & $3.59 \pm 0.21^{\mathrm{c}}$ & $26.95 \pm 1.05^{\mathrm{a}}$ \\
\hline Cupuacu & $8.48 \pm 0.02^{\mathrm{a}}$ & $0.23 \pm 0.07^{\mathrm{d}}$ & $3.13 \pm 0.12^{\mathrm{a}}$ & $6.59 \pm 0.07^{\mathrm{d}}$ & $1.55 \pm 0.07^{\mathrm{b}}$ & nd & nd \\
\hline Kiwi fruit & $8.91 \pm 0.19^{\mathrm{a}}$ & $2.66 \pm 0.05^{b}$ & $3.34 \pm 0.01^{\mathrm{a}}$ & $7.03 \pm 0.03^{\mathrm{d}}$ & $2.07 \pm 0.07^{b}$ & $2.48 \pm 0.09^{b}$ & nd \\
\hline Lemon & $8.98 \pm 0.15^{\mathrm{a}}$ & $2.73 \pm 0.02^{b}$ & $3.47 \pm 0.02^{\mathrm{a}}$ & $7.02 \pm 0.03^{\mathrm{d}}$ & $2.21 \pm 0.53^{b}$ & $2.23 \pm 0.03^{\mathrm{ab}}$ & $23.15 \pm 1.44^{\mathrm{ab}}$ \\
\hline Mango & $7.62 \pm 0.05^{\mathrm{a}}$ & $1.89 \pm 0.02^{\mathrm{a}}$ & $2.69 \pm 0.07^{\mathrm{c}}$ & $3.43 \pm 0.01^{\mathrm{a}}$ & $1.23 \pm 0.16^{\mathrm{c}}$ & $1.79 \pm 0.02^{\mathrm{a}}$ & nd \\
\hline Melon & $11.15 \pm 0.28^{b}$ & $3.55 \pm 0.84^{\mathrm{c}}$ & $4.17 \pm 0.27^{b}$ & $10.33 \pm 0.36^{\mathrm{e}}$ & $2.22 \pm 0.21^{\mathrm{b}}$ & $2.96 \pm 0.86^{\mathrm{b}}$ & nd \\
\hline Orange & $8.08 \pm 0.02^{\mathrm{a}}$ & $2.16 \pm 0.02^{\mathrm{a}}$ & $2.85 \pm 0.02^{\mathrm{c}}$ & $4.45 \pm 0.02^{\mathrm{c}}$ & $1.49 \pm 0.02^{\mathrm{c}}$ & $1.87 \pm 0.07^{\mathrm{a}}$ & nd \\
\hline Papaya & $8.44 \pm 0.49^{\mathrm{a}}$ & $1.82 \pm 0.13^{\mathrm{a}}$ & $2.96 \pm 0.02^{\mathrm{c}}$ & $5.32 \pm 0.04^{\mathrm{c}}$ & $1.55 \pm 0.26^{b}$ & $2.01 \pm 0.07^{\mathrm{a}}$ & $21.80 \pm 1.02^{b}$ \\
\hline Passion fruit & $8.44 \pm 0.23^{\mathrm{a}}$ & $2.36 \pm 0.02^{\mathrm{a}}$ & $1.26 \pm 0.07^{\mathrm{d}}$ & $5.42 \pm 0.09^{\mathrm{c}}$ & $1.21 \pm 0.16^{\mathrm{c}}$ & nd & nd \\
\hline Peach & $11.32 \pm 0.34^{\mathrm{b}}$ & $3.68 \pm 0.06^{\mathrm{c}}$ & $3.91 \pm 0.26^{\mathrm{a}}$ & $5.58 \pm 0.06^{\mathrm{c}}$ & $1.53 \pm 0.21^{\mathrm{c}}$ & $2.57 \pm 0.05^{b}$ & nd \\
\hline Pineapple & $8.40 \pm 0.33^{\mathrm{a}}$ & $2.30 \pm 0.17^{\mathrm{a}}$ & $3.12 \pm 0.09^{\mathrm{a}}$ & $4.57 \pm 0.24^{\mathrm{c}}$ & $1.34 \pm 0.52^{\mathrm{c}}$ & $2.01 \pm 0.06^{\mathrm{a}}$ & nd \\
\hline Raspberry & $8.40 \pm 0.09^{\mathrm{a}}$ & $2.20 \pm 0.02^{\mathrm{a}}$ & $3.10 \pm 0.01^{\mathrm{a}}$ & $4.48 \pm 0.25^{\mathrm{c}}$ & $1.52 \pm 0.18^{\mathrm{c}}$ & $1.97 \pm 0.02^{\mathrm{a}}$ & nd \\
\hline Red grape & $8.14 \pm 0.23^{\mathrm{a}}$ & $1.94 \pm 0.01^{\mathrm{a}}$ & $2.81 \pm 0.08^{\mathrm{c}}$ & $3.25 \pm 0.26^{\mathrm{a}}$ & $0.90 \pm 0.30^{\mathrm{a}}$ & $1.77 \pm 0.06^{\mathrm{a}}$ & nd \\
\hline Red guava & $8.61 \pm 0.14^{\mathrm{a}}$ & $2.55 \pm 0.02^{\mathrm{a}}$ & $3.16 \pm 0.05^{\mathrm{a}}$ & $6.09 \pm 0.09^{\mathrm{d}}$ & $14.4 \pm 0.50^{b}$ & $2.24 \pm 0.06^{\mathrm{ab}}$ & nd \\
\hline Soursop & $8.48 \pm 0.61^{\mathrm{a}}$ & $2.36 \pm 0.31^{\mathrm{a}}$ & $3.21 \pm 0.10^{\mathrm{a}}$ & $5.72 \pm 0.15^{\mathrm{c}}$ & $1.09 \pm 0.20^{\mathrm{b}}$ & $2.19 \pm 0.05^{\mathrm{ab}}$ & nd \\
\hline Strawberry & $9.15 \pm 0.08^{\mathrm{a}}$ & $2.69 \pm 0.03^{b}$ & $3.40 \pm 0.04^{\mathrm{a}}$ & $6.57 \pm 0.15^{\mathrm{d}}$ & $1.61 \pm 0.42^{b}$ & $2.21 \pm 0.03^{\mathrm{ab}}$ & nd \\
\hline Surinam cherry & $8.57 \pm 0.14^{\mathrm{a}}$ & $2.12 \pm 0.15^{\mathrm{a}}$ & $3.05 \pm 0.09^{\mathrm{a}}$ & $4.43 \pm 0.06^{\mathrm{c}}$ & $1.38 \pm 0.07^{\mathrm{b}}$ & $1.87 \pm 0.15^{\mathrm{a}}$ & nd \\
\hline Tangerine & $10.66 \pm 0.14^{b}$ & $3.48 \pm 0.17^{\mathrm{c}}$ & $2.55 \pm 0.07^{\mathrm{c}}$ & $5.40 \pm 0.80^{\mathrm{c}}$ & $1.49 \pm 0.50^{b}$ & $2.67 \pm 0.83^{b}$ & nd \\
\hline Men/day & $420 \mathrm{mg}$ & $2300 \mathrm{mg}$ & $700 \mathrm{mg}$ & $1000 \mathrm{mg}$ & $4700 \mathrm{mg}$ & not determinable & $1500 \mathrm{mg}$ \\
\hline Women/day & $320 \mathrm{mg}$ & $2300 \mathrm{mg}$ & $700 \mathrm{mg}$ & $1000 \mathrm{mg}$ & $4700 \mathrm{mg}$ & not determinable & $1500 \mathrm{mg}$ \\
\hline
\end{tabular}

${ }^{\mathrm{a}}$ Data are mean $\pm \mathrm{SD}$ values of three independent experiments and different letters indicate a significant difference according to analysis of variance and Tukey's post hoc test $(p \leq 0.05)$ for each mineral evaluated. nd: not detected. This table presents Dietary Reference Intakes (DRI) in italics and Dietary Recommendations in bold type, both for adult individuals (31-50 years old).

tion, regulation of blood sugar and cellular energy, reproduction, digestion, bone growth, and it aids in defense mechanisms against free radicals (Aschner and Aschner 2005). Copper promotes the formation of the mitochondrial heme, and the reduction of erythrocyte half-life in anemia (Conrad and Umbreit 2000). Diets low in copper are suggested as an explanation for much of the epidemiology and patho-physiology of ischemic heart disease (Klevay 2000). Zinc is essential as a catalyst for regulating the activity of over 300 specific zincdepended enzymes (McCall et al. 2000).

Chromium controls some physiological process in human body such as blood insulin regulation and lipid profile. Excessive consumption of chromium is rare since it is poorly absorbed (Mertz 1993). In this work, pulps of melon, orange and papaya (100 g) are able to provide more than $100 \%$ of the $\mathrm{Cr}$ DR.

Our results show the mineral profile of 23 frozen fruits, which may help to provide the flexibility needed to achieve the optimal dietary mineral content for a healthy human diet. However, it should be taken into account that the mineral content may be influenced by growing conditions, such as soil and geographical factors (Ercisli and Ohran 2007). In addition, the bioavailability of minerals seems to be dependent on cultivar, the environment and harvest year (Bohn et al. 2008). Some compounds such as ascorbic acid can help Fe absorption; on the other hand, iron uptake could be inhibited by strong chelators such phytic acid, some polyphenols and the divalent cations $\mathrm{Ca}, \mathrm{Zn}, \mathrm{Co}$ and $\mathrm{Mg}$. The rela- 
TABLE II

Level of microminerals $(\mathrm{mg} \%)$ in frozen fruits.

\begin{tabular}{|c|c|c|c|c|c|c|c|}
\hline Samples & $\mathrm{Fe}$ & $\mathrm{Mn}$ & $\mathrm{Cu}$ & $\mathrm{Zn}$ & $\mathrm{Cr}$ & $\mathrm{Si}$ & $\mathrm{Al}$ \\
\hline Acai & $0.51 \pm 0.28^{\mathrm{a} *}$ & $0.27 \pm 0.07^{\mathrm{a}}$ & nd & $0.20 \pm 0.01 \mathrm{a}$ & nd & $1.22 \pm 0.03^{\mathrm{a}}$ & nd \\
\hline Acerola & $0.26 \pm 0.85^{\mathrm{b}}$ & nd & nd & nd & nd & $1.35 \pm 0.07^{\mathrm{a}}$ & nd \\
\hline Apple & $0.54 \pm 1.32^{\mathrm{a}}$ & $0.29 \pm 0.04^{\mathrm{ab}}$ & $1.80 \pm 0.14^{\mathrm{a}}$ & $0.28 \pm 0.05^{\mathrm{ab}}$ & nd & $1.12 \pm 0.04^{\mathrm{a}}$ & $4.16 \pm 0.03^{\mathrm{a}}$ \\
\hline Black mulberry & $0.28 \pm 0.57^{\mathrm{b}}$ & $0.31 \pm 0.01^{\mathrm{b}}$ & nd & nd & nd & $1.28 \pm 0.02^{\mathrm{a}}$ & nd \\
\hline Cashew apple & $0.28 \pm 0.64^{\mathrm{b}}$ & nd & nd & nd & nd & $1.54 \pm 0.53^{\mathrm{a}}$ & nd \\
\hline Coconut & $0.24 \pm 0.42^{b}$ & $0.40 \pm 0.07^{\mathrm{b}}$ & nd & nd & nd & $1.60 \pm 0.07^{\mathrm{a}}$ & nd \\
\hline Cupuacu & $0.20 \pm 0.19^{\mathrm{c}}$ & $0.20 \pm 0.01^{\mathrm{a}}$ & $2.25 \pm 0.78^{\mathrm{ab}}$ & nd & nd & $1.30 \pm 0.06^{\mathrm{a}}$ & nd \\
\hline Kiwi fruit & $0.21 \pm 0.42^{b}$ & $0.19 \pm 0.02^{\mathrm{a}}$ & nd & nd & nd & nd & nd \\
\hline Lemon & $0.27 \pm 0.85^{\mathrm{b}}$ & $0.21 \pm 0.06^{\mathrm{a}}$ & $2.30 \pm 0.42^{\mathrm{b}}$ & $0.26 \pm 0.04^{\mathrm{ab}}$ & nd & $1.37 \pm 0.07^{\mathrm{a}}$ & $5.35 \pm 0.05^{\mathrm{b}}$ \\
\hline Mango & $0.18 \pm 0.76^{\mathrm{c}}$ & $0.17 \pm 0.06^{\mathrm{a}}$ & $1.85 \pm 0.35^{\mathrm{a}}$ & $0.21 \pm 0.03^{\mathrm{a}}$ & nd & $1.11 \pm 0.01^{\mathrm{a}}$ & $4.17 \pm 0.10^{\mathrm{a}}$ \\
\hline Melon & $0.28 \pm 0.07^{b}$ & $0.31 \pm 0.04^{b}$ & nd & nd & $0.15 \pm 0.01^{\mathrm{a}}$ & $1.66 \pm 0.60^{\mathrm{a}}$ & nd \\
\hline Orange & $0.28 \pm 0.92^{b}$ & $0.18 \pm 0.01^{\mathrm{a}}$ & nd & $0.30 \pm 0.08^{\mathrm{ab}}$ & $0.13 \pm 0.02^{\mathrm{a}}$ & $1.22 \pm 0.02^{\mathrm{a}}$ & $4.47 \pm 0.01$ \\
\hline Papaya & $0.16 \pm 0.28^{\mathrm{c}}$ & nd & $2.05 \pm 0.07^{\mathrm{c}}$ & $0.22 \pm 0.01^{\mathrm{a}}$ & $0.18 \pm 0.04^{\mathrm{b}}$ & $1.31 \pm 0.07^{\mathrm{a}}$ & $4.72 \pm 0.30^{\mathrm{a}}$ \\
\hline Passion fruit & $0.16 \pm 0.07^{\mathrm{c}}$ & $0.20 \pm 0.04^{\mathrm{a}}$ & $1.55 \pm 0.05^{\mathrm{a}}$ & $0.30 \pm 0.01^{\mathrm{b}}$ & nd & $1.26 \pm 0.04^{\mathrm{a}}$ & $4.73 \pm 0.07^{\mathrm{a}}$ \\
\hline Peach & $0.34 \pm 0.27^{\mathrm{b}}$ & nd & nd & nd & nd & $1.74 \pm 0.07^{\mathrm{a}}$ & nd \\
\hline Pineapple & $0.30 \pm 0.56^{\mathrm{b}}$ & $0.30 \pm 0.06^{\mathrm{b}}$ & nd & nd & nd & $1.25 \pm 0.06^{\mathrm{a}}$ & nd \\
\hline Raspberry & $0.25 \pm 0.42^{\mathrm{b}}$ & $0.21 \pm 0.05^{\mathrm{a}}$ & nd & nd & nd & $1.29 \pm 0.07^{\mathrm{a}}$ & nd \\
\hline Red grape & $0.18 \pm 0.07^{\mathrm{c}}$ & nd & $3.10 \pm 0.85^{\mathrm{c}}$ & nd & nd & $1.18 \pm 0.01^{\mathrm{a}}$ & $4.12 \pm 0.35^{\mathrm{a}}$ \\
\hline Red guava & $0.18 \pm 0.02^{\mathrm{c}}$ & $0.14 \pm 0.02^{\mathrm{a}}$ & nd & nd & nd & nd & nd \\
\hline Soursop & $0.18 \pm 0.21^{\mathrm{c}}$ & nd & nd & nd & nd & $1.29 \pm 0.06^{\mathrm{a}}$ & $4.83 \pm 0.25^{\mathrm{a}}$ \\
\hline Strawberry & $0.35 \pm 0.78^{b}$ & $0.28 \pm 0.03^{\mathrm{a}}$ & nd & nd & nd & $1.39 \pm 0.03^{\mathrm{a}}$ & $5.21 \pm 0.35^{\mathrm{b}}$ \\
\hline Surinam cherry & $0.14 \pm 0.28^{\mathrm{c}}$ & nd & nd & nd & nd & $1.32 \pm 0.04^{\mathrm{a}}$ & nd \\
\hline Tangerine & $0.61 \pm 0.21^{\mathrm{a}}$ & nd & nd & nd & nd & $3.82 \pm 0.42^{b}$ & nd \\
\hline Men/day & $8 \mathrm{mg}$ & $2.3 \mathrm{mg}$ & $0.9 \mathrm{mg}$ & $11 \mathrm{mg}$ & $35 \mu \mathbf{g}$ & not determinable & not determinable \\
\hline Women/day & $18 \mathrm{mg}$ & $1.8 \mathrm{mg}$ & $0.9 \mathrm{mg}$ & $8 \mathrm{mg}$ & $25 \mu \mathrm{g}$ & not determinable & not determinable \\
\hline
\end{tabular}

${ }^{a}$ Data are mean \pm SD values of three independent experiments and different letters indicate a significant difference according to analysis of variance and Tukey's post hoc test $(p \leq 0.05)$ for each mineral evaluated. nd: not detected. This table presents Dietary Reference Intakes (DRI) in italics and Dietary Recommendations in bold type, both for adult individuals (31-50 years old).

tionship among all fruit constituents and between them and other elements that are present in the diet should be better studied.

\section{ACKNOWLEDGMENTS}

We thank the Universidade de Caxias do Sul (Caxias do Sul, RS, Brasil), Laboratório de Implantação Iônica, Instituto de Física, UFRGS (Porto Alegre, RS, Brasil) and the Fundação de Amparo à Pesquisa do Estado do Rio Grande do Sul for their help and financial support.

\section{RESUMO}

As frutas são ricas em minerais, sendo estes essenciais para uma grande variedade de processos metabólicos e fisiológicos no corpo humano. A utilização de frutas congeladas tem se ampliado nos últimos anos, não só na preparação de sucos, mas também como matéria-prima para iogurtes, doces, biscoitos, bolos, sorvetes e alimentos infantis. No entanto, até o momento não há dados sobre o perfil mineral de frutas congeladas. Este trabalho é o primeiro banco de dados para quantificar os níveis de minerais em 23 amostras de frutas congeladas, bastante consumidas em todo o mundo e de algumas frutas nativas da floresta amazônica, Brasil. Considerando-se as Referências de Ingestão Diárias, $100 \mathrm{~g}$ de frutas congeladas podem fornecer $0,2-2,8 \%$ de macro e de 2,5 a $100 \%$ dos microminerais para adultos (31-50 anos). Embora as diferenças geográficas devam ser consideradas, estes dados ajudam para o plano de dietas e desenvolvimento de intervenções junto à população com o objetivo de prevenir doenças crônicas.

Palavras-chave: dieta, recomendações dietéticas, Referências de Ingestão Diária, frutas congeladas, minerais. 


\section{REFERENCES}

Alsafwah S, Laguardia SP, Arroyo M, Dockery BK, BHATTACHARYA SK, AHOKAS RA AND NEWMAN KP. 2007. Congestive heart failure is a systemic illness: a role for minerals and micronutrients. Clin Med Res 5: 238-243.

AsCHner JL AND AsChner M. 2005. Nutritional aspects of manganese homeostasis. Mol Aspects Med 26(4-5): 353-362.

Bastos VlfC, Cunha JCB, Lima JS and Castro FARIA MV. 1991. Brain acetylcholinesterase as an in vitro detector of organophosphorus and carbamate insecticides in water. Water Res 25: 835-840.

Bohn L, Meyer AS And Rasmussen SK. 2008. Phytate: impact on environment and human nutrition. A challenge for molecular breeding. J Zhejiang Univ Sci B 9: 165191.

Bonjour JP, Guéguen L, Palacios C, Shearer MJ AND WEAVER CM. 2009. Minerals and vitamins in bone health: the potential value of dietary enhancement. $\mathrm{Br} \mathrm{J}$ Nutr 101(11): 1581-1596.

Campbell JL, Hopman TL and Maxwell JA. 2000. The Guelph PIXE software package III: alternative proton database. Nucl Instrum Methods Phys Res B 170: 193-204.

DE Lima JS, Cunha Bastos J And Cunha Bastos VLF. 1996 Methyl parathion activation by partially purified rat brain fraction. Toxicol Lett 87: 53-60.

Conrad ME And Umbreit JN. 2000. Disorders of iron metabolism. N Engl J Med 342(17): 1293-1294.

Donabedian H. 2006. Nutritional therapy and infectious diseases: a two-edged sword. Nutr J 5: 21-31.

ERCISLI S AND OHRAN E. 2007. Chemical composition of white (Morus alba), red (Morus rubra) and black (Morus nigra) mulberry fruits. Food Chem 103: 1380-1384.

Franke Si, Pra D, Giulian R, Dias JF, Yoneama ML, DA Silva J, ERdtMann B and Henriques JA. 2006. Influence of orange juice in the levels and in the genotoxicity of iron and copper. Food Chem Toxicol 44: 425-435.

Genkinger JM, Platz EA, Hoffman SC, Comstock GW AND Helzlsouer KJ. 2004. Fruit, vegetable, and antioxidant intake and all-cause, cancer, and cardiovascular disease mortality in a communitydwelling population in Washington County, Maryland. Am J Epidemiol 160: 1223-1233.
Halliwell B And Gutteridge JMC. 2007. Free Radicals in Biology and Medicine, Oxford, n. 4. New York, $777 \mathrm{p}$.

Hassimotto NM, Genovese Mi And Lajolo FM. 2005. Antioxidant activity of dietary fruits, vegetables, and commercial frozen fruit pulps. J Agric Food Chem 53: 2928-2935.

IOM. 2004. Institute of Medicine. Dietary Reference Intakes for Water, Potassium, Sodium, Chloride, and Sulfate. Available online.

$<$ http://www.nap.edu/catalog/10925.html>.

Johansson SA, CAMPBell JL AND MALMQVist KG. 1995. Particle induced x-ray emission spectrometry (PIXE), Wiley: New York, 451 p.

Karppanen H, Karppanen P And MervaAla E. 2005. Why and how to implement sodium, potassium, calcium, and magnesium changes in food items and diets? J Hum Hypertens 19: 10-19.

Kern AL, Bonatto D, Dias JF, Yoneama ML, BrenDEL M AND HENRIQUES JAP. 2005. The importance of yeast Alr proteins in cadmium detoxification as indicated by particle-induced X-ray emission and phenotypic analyses. X-ray spectrom 34: 355-358.

KLEVAY LM. 2000. The illness and death of a female hyena poisoned by zinc ingested as pennies. J Zoo Wildl Med 31(3): 289-290.

Krall E. 2000. Calcium and vitamin D. In: Exercise, Nutrition, and the Older Woman: Wellness for Women over Fifty, Washington: CRC Press, p. 173-181.

Lово DN. 2004. Fluid, electrolytes and nutrition: physiological and clinical aspects. Proc Nutr Soc 63(3): 453-66.

MAHAN KL AND EscotT-STUMP S. 2005. Krause's Food, Nutrition \& Diet Therapy, Philadelphia: Saunders, n. 12, $13520 \mathrm{p}$.

McCall KA, Huang C And Fierke CA. 2000. Function and mechanism of zinc metalloenzymes. J Nutr 130: 1437-1446.

Maxwell JA, Campbell JL and Teesdale WJ. 1989. The Guelph PIXE software package. Nucl Instrum Methods Phys Res B 43: 218-230.

Mertz W. 1993. Chromium in human nutrition: a review. J Nutr 123: 626-633.

Pellerano RG, Mazza SS, Marigliano RA And MARCHEVSKY EJ. 2008. Multielement analysis of Argentinean lemon juices by instrumental neutronic activation analysis and their classification according to geographical origin. J Agric Food Chem 56: 5222-5225. 
Spada PD, De Souza GG, Bortolini GV, Henriques JA AND SALVADOR M. 2008. Antioxidant, mutagenic, and antimutagenic activity of frozen fruits. J Med Food 11: 144-151.

TITZE J AND Ritz E. 2009. Salt and its effect on blood pressure and target organ damage: new pieces in an old puzzle. J Nephrol 22: 177-189.
WiLliams M. 2006. Dietary supplements and sports performance: metabolites, constituents, and extracts. J Int Soc Sports Nutr 3: 1-5.

ZHI J, MOORE R AND Kanitra L. 2003. The effect of short-term (21-day) orlistat treatment on the physiologic balance of six selected macrominerals and microminerals in obese adolescents. J Am Coll Nutr 22: 357-362. 